\title{
Chloroform Formation by Chlorination of Aqueous Algae Suspensions: Online Monitoring via Membrane Introduction Mass Spectrometry
}

\author{
João T. Borges, ${ }^{*, a}$ Regina Sparrapan, ${ }^{a}$ José R. Guimarães, ${ }^{b}$ Marcos N. Eberlin ${ }^{a}$ and Rodinei Augustic \\ ${ }^{a}$ Laboratório ThoMSon de Espectrometria de Massas, Instituto de Química, Universidade Estadual de Campinas, \\ 13083-970 Campinas-SP, Brazil \\ ${ }^{b}$ Departamento de Engenharia Civil, Universidade Estadual de Campinas, 13083-970 Campinas-SP, Brazil \\ 'Universidade Federal de Minas Gerais, Departamento de Química, 31270-901 Belo Horizonte-MG, Brazil
}

A técnica MIMS (membrane introduction mass spectrometry) foi utilizada para monitorar a formação de clorofórmio durante a cloração de suspensões aquosas de várias espécies brasileiras de algas verdes e azuis (Microcystis panniformis, Selenastrum sp., Scenedesmus sp., Monoraphidium sp. (strain 354), Monoraphidium sp. (strain 960), and Staurastrum sp.). Foram avaliadas as influências de parâmetros como temperatura, $\mathrm{pH}$, concentração inicial de hipoclorito de sódio, filtração e tempo de reação. Foi constatado que o teor de clorofórmio é fortemente dependente da espécie de alga e também é favorecido com o aumento da temperatura, $\mathrm{pH}$, dosagem de cloro inicial e do tempo de reação. Amostras de suspensões de algas submetidas a filtração produziram menores quantidades de clorofórmio em comparação com as amostras brutas.

Membrane introduction mass spectrometry (MIMS) was used to perform on-line monitoring of the chloroform formation via the chlorination of aqueous suspensions of several green and blue-green Brazilian algae (Microcystis panniformis, Selenastrum sp., Scenedesmus sp., Monoraphidium sp. (strain 354), Monoraphidium sp. (strain 960), and Staurastrum sp.). The influence of major parameters, such as temperature, $\mathrm{pH}$, initial concentration of sodium hypochloride, filtration, and reaction time, on chloroform formation was evaluated. It was verified that the chloroform formation is strongly dependent on the alga type and is favored by high temperatures, $\mathrm{pH}$, sodium hypochloride initial concentration and reaction time. Finally, filtered algae samples produce smaller amounts of chloroform in comparison to the rough suspension.

Keywords: chlorination, sodium hypochloride, blue-green Brazilian algae, chloroform formation, membrane introduction mass spectrometry

\section{Introduction}

Lakes and reservoirs are characterized by a long water residence time and low flow rate. Therefore, they are subject to high accumulation of nutrients, which leads to an unrestrained increase in the amount of algae. Such water bodies are commonly used for public water supply after conventional water treatment. During chlorination, algal biomass and extracellular products may act as chloroform precursors, especially if water comes from springs with high eutrophication levels, which leads to high concentrations of these compounds. ${ }^{1}$

*e-mail: thtborges@ig.com.br
In 1977, Hoehn, et al. ${ }^{2}$ observed a seasonal variation in the amount of total halogenated matter (THM: chloroform, bromodichloromethane, dibromochloromethane, and tribromomethane), in a water-supply system in the State of Virginia, USA. The variation could not be explained by changes in temperature and organic carbon concentration. The data obtained in this study suggest that algal biomass and extracellular products, along with other factors, such as humic and fulvic acids content, lead to chloroform formation after water chlorination.

Based on this observation, the importance of algal biomass and extracellular products as chloroform precursors have been investigated. For instance, Karimi and Singer ${ }^{3}$ performed a study in an eutrophicated reservoir and observed a correlation between chlorination and chloroform 
formation. Several factors, such as species diversity over the year or even the decrease in the amount of algae in certain periods influenced chloroform formation.

Graham et al. ${ }^{4}$ verified that the formation of chloroform from both algal biomass (unfiltered sample) and extracellular products (filtered sample) depends on $\mathrm{pH}$, reaction time, temperature and on the ratio between hypochloride (active chlorine) concentration and the content of total organic carbon (TOC).

In their study on the chlorination of an aqueous suspension of Scenedesmus quadricalda by hypochloride, Plummer and Edwald ${ }^{5}$ concluded that pre-ozonization and higher reaction times led to higher chloroform formation rates. The authors associated this increase to the dissolved organic carbon derived from the lyses of algae cells.

Membrane introduction mass spectrometry (MIMS) ${ }^{6}$ is one of the simplest, fastest, and most sensitive techniques for the analysis of volatile $\mathrm{e}^{7-9}$ and semi-volatile $\mathrm{e}^{10,11}$ organic compounds in water as well as in other matrixes such as air, soil and other solvents. ${ }^{12-18}$ In this technique volatile and semi-volatile organic compounds permeate hydrophobic membranes, usually polydimethylsiloxanes (PDMS), preferentially to water and other polar substances. MIMS can be applied to real-time and in-situ monitoring of chemical processes, such as: $(a)$ conversion of chlorine to chloramines, an environmentally relevant reaction; ${ }^{19-21}$

(b) chlorination of phenol and related compounds, models of humic substances by sodium hypochloride ${ }^{22}$ (c) oxidation of benzene derivative by the Fenton's reagent; ${ }^{23}$ (d) photolysis of aryl methyl ester in aqueous and aqueousmethanolic solutions; ${ }^{24}(e)$ hydrolysis of epichlorohydrin, a significant compound in the polymer industry; ${ }^{25}$ and (f) catalytic hydrodechlorination of aromatic chlorides, an important process to treat organochloro compounds. ${ }^{26}$

In this work, MIMS is applied to an online and real time monitoring of chloroform formation by the chlorination of aqueous suspensions of a number of green and bluegreen Brazilian alga as a function of major parameters as temperature, $\mathrm{pH}$, initial sodium hypochloride concentration, filtration and reaction time.

\section{Materials and Methods}

\section{Reagents, algae culture and maintenance}

UV-grade chloroform were purchased from Supelco and used with no further purification. Algae species were supplied by the bank of algae cultures from the Laboratório de Ficologia, Instituto de Botânica, Universidade Federal de São Carlos, Brazil. ${ }^{27}$ All glassware was sterilized before incubation and transplantation. Axenic culture cells (bacterium- and fungus-free) in exponential growth phase were used as inoculum. The chosen species were inoculated in specific culture media. Cyanophycea, (Microcystis panniformis) was incubated in an ASM-1 culture medium, whereas Chlorophyceae (Selenastrum sp., Scenedesmus sp., Monoraphidium sp. (strain 354), Monoraphidium sp. (strain 960) and Staurastrum sp.) were inoculated in a WCC culture medium. The algae were from the main lake of Barra Bonita, São Paulo State, Brazil.

Approximately $2.0 \mathrm{~mL}$ of the algae inoculum was put into a 200-mL Erlenmeyer flask containing the sterile culture medium. The suspension was homogenized and incubated in aerobic conditions at $20^{\circ} \mathrm{C}$. When an increase in concentration was observed, indicated by a greenish color, the suspension was transferred to a $100 \mathrm{~mL}$ flatbottom flask and completed with the specific culture medium solution and placed in an incubation chamber. The chamber was connected to a timer and the photoperiod was set to twelve hours of light exposition and twelve hours in the dark, also at $20^{\circ} \mathrm{C}$ during 7 days. Asepsis was ensured by cotton filters in the venting and in sample collection systems. The aqueous suspension was then filtered and the algae material isolated upon complete water removal at ambient temperature.

\section{Chloroform formation and residual hypochloride measurement}

To determine the amount of chloroform formed, $0.5 \mathrm{~g}$ of the dried algae material was put into a $100 \mathrm{~mL}$ flatbottom flask containing approximately $90 \mathrm{~mL}$ of distilled water. In a typical run, sodium hypochloride was added to yield a final concentration of $10 \mathrm{mg} \mathrm{L}^{-1}$, the $\mathrm{pH}$ adjusted to 7 by the addition of $\mathrm{HCl} 0.1 \mathrm{~mol} \mathrm{~L}^{-1}$ and the final volume completed with distilled water. The system was kept at a constant temperature $\left(25^{\circ} \mathrm{C}\right)$ during $24 \mathrm{~h}$ and the chloroform concentration determined by using the MIMS apparatus (Figure 1). Distinct experimental conditions than these ones were also used which are mentioned throughout the text. The residual hypochloride was determined by adding an excess of potassium iodide (KI) followed by the titration of the formed iodine $\left(\mathrm{I}_{2}\right)$ with standardized sodium thiosulphate $\left(\mathrm{Na}_{2} \mathrm{~S}_{2} \mathrm{O}_{3}\right)$ solution. ${ }^{28}$

\section{MIMS: general aspects and performance}

Experiments were carried out in an Extrel mass spectrometer (Pittsburgh, PA) equipped with a flow-through type membrane probe ${ }^{29}$ mounted near to the ion source. A $250 \mu \mathrm{m}$ silicone membrane (Dow Corning Silastic 500-3) with an exposed area of $5 \mathrm{~mm}^{2}$ (flat sheet) was used. Mass 


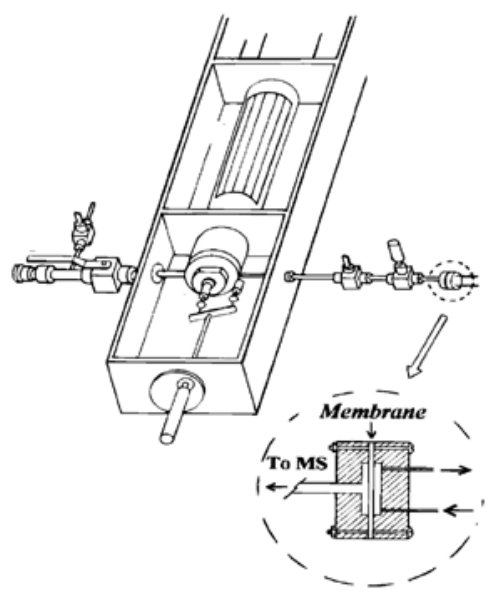

Figure 1. Schematic representation of the MIMS system.

spectra were obtained by electron ionization at $70 \mathrm{eV}$. Selective ion monitoring (SIM) was used to monitor the ion of $m / z, 83$, which is characteristic of chloroform. Figure 1 shows a schematic representation of the MIMS device. In a typical experiment, the aqueous solutions of the standards or samples were pumped (by a peristaltic pump) through the membrane probe at a flow rate of $5 \mathrm{~mL} \mathrm{~min}^{-1}$ and subsequently directed to a discarding flask. The membrane was cleaned with water immediately after the signal had achieved its maximum intensity. After the baseline was attained, the procedure was repeated for either a new sample or standard. Some examples of the resultant MIMS profiles are presented (Figure 2).

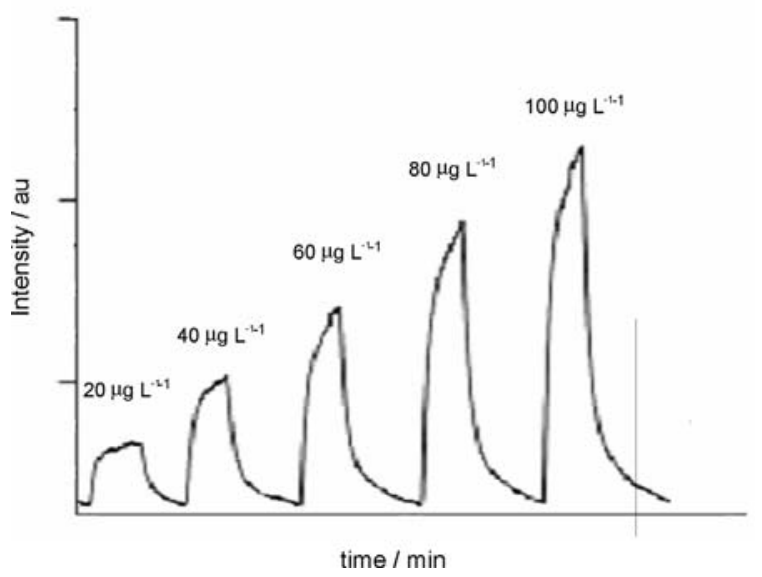

Figure 2. MIMS profile for the standard chloroform aqueous solutions. Chloroform was detected via the monitoring of the ion of $\mathrm{m} / \mathrm{z} 83$.

Calibration curve was built by injecting aqueous solutions of chloroform at concentrations of 20,40, 60 and 80,120 and $160 \mu \mathrm{g} \mathrm{L}^{-1}$ in duplicate into the MIMS system.

\section{Results and Discussion}

Figure 2 shows the MIMS profile for the SIM of the ion of $\mathrm{m} / \mathrm{z} 83$, the most intense in the $70 \mathrm{eV}$ EI mass spectrum of chloroform, ${ }^{30}$ upon the injection of the chloroform standard solutions $\left(20-100 \mu \mathrm{g} \mathrm{L}^{-1}\right)$. From the data of Figure 2, an analytical curve (not shown), i.e. chloroform concentration as a function of the MIMS peak height, was built and a good linear relationship was observed $\left(\mathrm{R}^{2}=0.998\right)$. This analytical curve was thus used to estimate the chloroform concentration for each experiment, as following described.

Temperature effect on chlorination of aqueous suspensions of Microcystis panniformis algae

In order to investigate the effect of temperature on chloroform formation, chlorination of aqueous suspensions of Microcystis panniformis $(0.5 \mathrm{~g}$ in $100 \mathrm{~mL}$ see Experimental section for more details) with sodium hypochloride at initial concentrations of 10, 15, $20 \mathrm{mg} \mathrm{L}^{-1}$ were performed using two distinct temperatures: 20 and 25 ${ }^{\circ} \mathrm{C}$. The solution $\mathrm{pH}$ was adjusted to 6 by the addition of $\mathrm{HCl}$ $0.1 \mathrm{~mol} \mathrm{~L}^{-1}$ and the reaction time was $24 \mathrm{~h}$. The results shown in Table 1 indicate that chloroform formation is influenced by temperature. As temperature rises from 20 to $25^{\circ} \mathrm{C}$, an increase of approximately $21 \%$ (average) in the chloroform concentration is observed. This observation corroborates previous results, which indicate that chloroform formation is directly dependent on temperature. For instance, Watcher and Andelman ${ }^{31}$ observed that the amount of chloroform formed depends on the temperature and reaction time, especially in the first $24 \mathrm{~h}$.

Table 1. Chloroform concentration $\left(\mu \mathrm{g} \mathrm{L}^{-1}\right)$ formed upon the chlorination of aqueous suspensions of Microcystis panniformis algae with sodium hypochloride at several initial concentrations $\left(\mathrm{mg} \mathrm{L}^{-1}\right)$ and at two different temperatures $\left(20\right.$ and $\left.25^{\circ} \mathrm{C}\right)(\mathrm{pH} 6$; reaction time $24 \mathrm{~h})$

\begin{tabular}{lcc}
\hline Initial concentration of & Chloroform concentration $/(\mu \mathrm{g} \mathrm{L}-1)$ \\
$\mathrm{NaClO} /\left(\mathrm{mg} \mathrm{L}^{-1}\right)$ & $20^{\circ} \mathrm{C}$ & $25^{\circ} \mathrm{C}$ \\
\hline 10 & 26 & 30 \\
15 & 36 & 47 \\
20 & 43 & 51 \\
\hline
\end{tabular}

pH effect on chlorination of aqueous suspensions of Microcystis panniformis algae

The effect of $\mathrm{pH}$ on chloroform formation was also evaluated. Thus, experiments were performed using aqueous suspensions $(0.5 \mathrm{~g}$ in $100 \mathrm{~mL}$ - see Experimental section for more details) of Microcystis panniformis at two 
different pH: 6 and 9 (see further experimental conditions at the caption of Table 2). The results shown in Table 2 indicate that when $\mathrm{pH}$ is raised from 6 to 9 an increase of approximately $40 \%$ in the chloroform formation is observed in all cases. Similar results were obtained by Oliver and Shindler ${ }^{32}$ whose performed studies on aqueous suspensions of seven different green algae species at $\mathrm{pH} 7$ and 11 . They observed that chloroform formation was higher at $\mathrm{pH} 11$ than at $\mathrm{pH}$ 7. The amount of chloroform formed at a higher $\mathrm{pH}$ was 3 to 4 times larger than that formed at neutral $\mathrm{pH}$. Wachter and Andelman ${ }^{31}$ also studied the effects of $\mathrm{pH}$ on the chloroform formation in algae suspensions of Anabaena flosaquae, Chlorella vulgari, and Chlorella pyrenoidosa. In their studies, these authors adjusted the $\mathrm{pH}$ of the suspensions to 2,7 , and 12 , and noted a gradual increase in the amount of chloroform formed.

Table 2. Chloroform concentration $\left(\mu \mathrm{g} \mathrm{L}^{-1}\right)$ formed upon the chlorination of aqueous suspensions of Microcystis panniformis with sodium hypochloride at several initial concentrations $\left(\mathrm{mg} \mathrm{L}^{-1}\right)$ and at two different $\mathrm{pH}(6$ and 9$)\left(\mathrm{T} 25^{\circ} \mathrm{C}\right.$; reaction time $\left.24 \mathrm{~h}\right)$

\begin{tabular}{lcc}
\hline $\begin{array}{l}\text { Initial concentration of } \\
\mathrm{NaClO} /\left(\mathrm{mg} \mathrm{L}^{-1}\right)\end{array}$ & $\begin{array}{c}\text { Chloroform concentration / }\left(\mu \mathrm{g} \mathrm{L}^{-1}\right) \\
\mathrm{pH} \mathrm{6}\end{array}$ & $\mathrm{pH} \mathrm{9}$ \\
\hline 10 & 30 & 42 \\
15 & 47 & 66 \\
20 & 51 & 71 \\
\hline
\end{tabular}

Influence of filtered and unfiltered samples on chloroform formation during chlorination of aqueous suspensions of green algae

In order to investigate the effect of soluble compounds excreted by algae or deriving from cellular lyses on chloroform formation, experiments using unfiltered and filtered samples were performed. To allow the soluble compounds be extracted from the algae cells, the suspensions were filtered after a contact time of $36 \mathrm{~h}$ with a $1.2 \mu \mathrm{m}$ pore diameter $\mathrm{GF} / \mathrm{C}$ membrane with a diameter of $47 \mathrm{~mm}$. Filtered samples were prepared also to simulate a common water treatment procedure. ${ }^{33}$ These assays were performed by using suspensions of green algae $(0.5 \mathrm{~g}$ in $100 \mathrm{~mL}$ ) and the samples were chlorinated with sodium hypochloride at $13 \mathrm{mg} \mathrm{L}^{-1}$. Further experimental conditions are given in the caption of Table 3 .

It is evident that chloroform concentration is higher for unfiltered samples. This increase indicates that the algae in suspension, which can be removed by flocculation during the water treatment process, have a significant effect on chloroform formation. The results obtained from this study suggest that it is important to control algae proliferation in water sources used for public supply, since
Table 3. Chloroform formation in unfiltered and filtered aqueous suspensions of several green algae species (initial concentration of sodium hypochloride $13 \mathrm{mg} \mathrm{L}^{-1}$; T $25{ }^{\circ} \mathrm{C}$; pH 7; reaction time $24 \mathrm{~h}$ )

\begin{tabular}{lc}
\hline Algae & Chloroform concentration / $\left.(\mu \mathrm{g} \mathrm{L})^{-1}\right)^{\mathrm{a}}$ \\
\hline Selenastrums sp. & $130 / 60$ \\
Scenedesmus sp. & 89 / 47 \\
Monoraphidium sp. Strain 354 & 93 / 59 \\
Monoraphidium sp. Strain 960 & $36 / 15$ \\
Staurastrum sp. & 112 / 60 \\
\hline a unfiltered / filtered samples.
\end{tabular}

${ }^{a}$ unfiltered / filtered samples.

they contribute to the formation of halogenated organic compounds, especially chloroform, even after filtration. Therefore, the removal of suspended material from water prior to chlorination is essential since the intracellular material is transferred to water and becomes available to form chloroform and possibly other organochlorinated compounds.

Similar results were obtained by Graham $^{34}$ who performed laboratory studies with the algae Anabaena flosaquae and Asterionella formosa and demonstrated that the filtered material was also able to form chloroform during chlorination. In a related study, Cheng and $\mathrm{Chi}^{35}$ analyzed the water of three reservoirs in Taiwan and observed that chloroform formation is higher after algae blooms as a result of the dissolved organic matter deriving from cell lyses. According to the authors, this effect is due to the difficulty in removing this organic matter by conventional flocculation/sedimentation processes.

Sodium hypochloride initial concentration effect on chloroform formation during chlorination of aqueous suspensions of green algae

Unfiltered aqueous suspensions of several species of green algae $(0.5 \mathrm{~g}$ in $100 \mathrm{~mL})$ were chlorinated with sodium hypochloride (initial concentrations of 6.5 and $13.0 \mathrm{mg} \mathrm{L}^{-1}$ ) and the solution $\mathrm{pH}$ adjusted to 7 by the addition of $\mathrm{HCl}$ $0.1 \mathrm{~mol} \mathrm{~L}^{-1}$. Table 4 presents the chloroform concentration, estimated by MIMS (profile not shown), and the residual hipochloride, achieved after a reaction time of $24 \mathrm{~h}$ at a temperature of $25^{\circ} \mathrm{C}$. The initial hypochloride dosage has a significant effect on the amount of chloroform formed. Thus, an increase of $48 \%$ to $138 \%$ in the chloroform concentration is observed, depending on the algae species, when the hypochloride concentration is increased. This distinct enhancement in the chloroform concentration therefore indicates that the expenditure of hypochloride to form chloroform depends on the algae species. Analogous data were obtained by Wachter and Andelman ${ }^{31}$ during the chlorination of the algae species Anabaena flosaqueae and 
Chlorella vulgaris. They observed a higher chloroform formation in an aqueous suspension of Chlorella vulgaris.

Table 4. Chloroform concentration $\left(\mu \mathrm{g} \mathrm{L} \mathrm{L}^{-1}\right)$ and residual hypochloride (mg $\mathrm{L}^{-1}$ ) obtained upon the chlorination of unfiltered aqueous suspensions of several species of green algae $\left(\mathrm{T} 25^{\circ} \mathrm{C} ; \mathrm{pH} 7\right.$; reaction time $24 \mathrm{~h}$ )

\begin{tabular}{lcc}
\hline Algae species & Initial $\mathrm{NaClO}$ concentration $/\left(\mathrm{mg} \mathrm{L}^{-1}\right)$ \\
\hline Selenastrums sp. & 6.5 & 13 \\
Scenedesmus $\mathrm{sp}$. & $72 / 0.2^{\mathrm{a}}$ & $130 / 2.2^{\mathrm{a}}$ \\
Monoraphidium $\mathrm{sp}$. & $60 / 0.1^{\mathrm{a}}$ & $89 / 0.9^{\mathrm{a}}$ \\
Strain 354 & $57 / 0.2^{\mathrm{a}}$ & $93 / 1.5^{\mathrm{a}}$ \\
Monoraphidium $\mathrm{sp}$. & & \\
Strain 960 & $21 / 0.6^{\mathrm{a}}$ & $36 / 3.5^{\mathrm{a}}$ \\
Staurastrum $\mathrm{sp}$. & $47 / 2.3^{\mathrm{a}}$ & $112 / 3.5^{\mathrm{a}}$ \\
\hline
\end{tabular}

${ }^{a}$ chloroform concentration $\left(\mu \mathrm{g} \mathrm{L}^{-1}\right) /$ residual hypochloride $\left(\mathrm{mg} \mathrm{L}^{-1}\right)$.

Reaction time effect on chloroform formation during chlorination of aqueous suspensions of green algae

Chlorination of algae aqueous suspensions $(0.5 \mathrm{~g}$ in $100 \mathrm{~mL}$ ) with $\mathrm{NaClO} 13 \mathrm{mg} \mathrm{L}^{-1}$ were done at $25^{\circ} \mathrm{C}$, at $\mathrm{pH}$ 7. Aliquots were taken at several reaction times and the chloroform content (Table 5) determined by MIMS (profiles not shown).

Table 5. Reaction time effect in chloroform formation during chlorination of unfiltered aqueous suspensions of several green algae (initial concentration of $\mathrm{NaClO} 13 \mathrm{mg} \mathrm{L}^{-1}$; $\mathrm{T} 25^{\circ} \mathrm{C}$; $\mathrm{pH} 7$ )

\begin{tabular}{lcccc}
\hline \multirow{2}{*}{ Samples } & \multicolumn{4}{c}{ Reaction time / (h) } \\
\hline $\begin{array}{l}\text { Monoraphidium sp. } \\
\text { Strain } 354\end{array}$ & $24^{\mathrm{a}}$ & $93^{\mathrm{a}}$ & $183^{\mathrm{a}}$ & $206^{\mathrm{a}}$ \\
$\begin{array}{l}\text { Monoraphidium sp. } \\
\text { Strain } 960\end{array}$ & $25^{\mathrm{a}}$ & $36^{\mathrm{a}}$ & $108^{\mathrm{a}}$ & $113^{\mathrm{a}}$ \\
Staurastrum $\mathrm{sp}$. & $54^{\mathrm{a}}$ & $112^{\mathrm{a}}$ & $231^{\mathrm{a}}$ & $244^{\mathrm{a}}$ \\
\hline
\end{tabular}

${ }^{a}$ Chloroform concentration $\left(\mathrm{mg} \mathrm{L}^{-1}\right)$.

As expected, the longer the reaction time the higher the chloroform formation. It is also clear that the highest chloroform formation rate occurs during the first four hours of reaction between $\mathrm{NaClO}$ and the organic material.

In a related study, Wachter and Andelman ${ }^{31}$ investigated the effect of the reaction time on the chlorination of aqueous suspensions of several species of algae. The authors observed, in agreement with the results described herein, a constant increase in the chloroform formation as a function of time.

\section{Conclusions}

The present study shows that MIMS provides an efficient technique to monitor chloroform formation upon the chlorination of algae aqueous suspension. The on-line monitoring performed by MIMS allowed us to verify accurately and quickly the influence of major parameters influencing chloroform formation, $i$. $e$. sodium hypochloride concentration, temperature, $\mathrm{pH}$, filtration, and reaction time. These results contribute therefore to the better knowledge of the chlorination process of algae in aqueous medium, thus to control this important process that is currently a major concern for water supply treatment.

\section{Acknowledgments}

The authors thank the Brazilian research foundations FAPESP and CNPq for financial support.

\section{References}

1. Manahan, S.E.; Environmental Chemistry, CRC Press: Boca Raton, 2004.

2. Hoehn, R.C.; Randall, C.W.; Bell, F.A.; Shaffer, P.T.B.; J. Environ. Eng. Div. Asce, 1977, 103, 803.

3. Karimi, A.A.; Singer, P.C.; J. Am. Water Works Ass. 1991, 83, 84.

4. Graham, N. J. D.; Wardlaw, V. E.; Perry, R.; Jiang, J. Q.; Water Sci. Technol. 1998, 37, 83.

5. Plummer, J.D.; Edzwald, J.K.; Water Sci. Technol. 1998, 37, 49.

6. Johnson, R.C.; Cooks, R.G.; Allen, T.M.; Cisper, M.E.; Hemberger, P.H.; Mass Spectrom. Rev. 2000, 19, 1.

7. Moraes, L.A.B.; Eberlin, M.N.; Cagnon, J.R., Urbano, L.H.; Analyst 2000, 125, 1529.

8. Sharara, K.; Mansouri, J.; Fane, A.G.; Crisp, P.T.; Calderon, P.; Guilhaus, M.; Water Sci. Technol. 2000, 41, 373.

9. Creaser, C.S.; Lamarca, D.G.; dos Santos, L.M.F.; LoBiundo, G.; New, A.P.; J. Chem. Technol. Biotechnol. 2003, 78, 1193.

10. Lauritsen, F.R.; Mendes, M.A.; Aggerholm, T.; Analyst 2000, $125,211$.

11. Lauritsen, F.R.; Rose, J.; Analyst 2000, 125, 1577.

12. Riter, L.S.; Takats, Z.; Charles, L.; Cooks, R.G.; Rapid Commun. Mass Spectrom. 2001, 15, 1520.

13. Alberici, R.M.; Zampronio, C.G.; Poppi, R.J.; Eberlin, M.N.; Analyst 2002, 127, 230

14. Alberici, R.M.; Sparrapan, R.; Jardim, W.F.; Eberlin, M.N.; Environ. Sci. Technol. 2001, 35, 2084.

15. Allen, T.M.; Falconer, T.M.; Cisper, M.E.; Borgerding, A.J.; Wilkerson, C.W.; Anal. Chem. 2001, 73, 4830.

16. Kostiainen, R.; Kotiaho, T.; Mattila, I.; Mansikka, T.; Ojala, M.; Ketola, R.A.; Anal. Chem. 1998, 70, 3028. 
17. Riter, L.S.; Charles, L.; Turowski, M.; Cooks, R.G.; Rapid Commun. Mass Spectrom. 2001, 15, 2290.

18. Creaser, C.S.; Lamarca, D.G.; Brum, J.; Werner, C.; New, A.P.; dos Santos, L.M.F.; Anal. Chem. 2002, 74, 300.

19. Kotiaho, T.; Hayward, M.J.; Cooks, R.G.; Anal. Chem. 1991, 63, 1794.

20. Shang, C.; Blatchley, E.R.; Environ. Sci. Technol. 1999, 33, 2213.

21. Shang, C.; Gong, W.L.; Blatchley, E.R.; Environ. Sci. Technol. 2000, 34, 1721.

22. Rios, R.V.R.A.; da Rocha, L.L.; Vieira, T.G.; Lago, R.M.; Augusti, R.; J. Mass Spectrom. 2000, 35, 618.

23. Augusti, R.; Dias, A.O.; Rocha, L.L.; Lago, R.M.; J. Phys. Chem. A. 1998, 102, 10723.

24. Wong, P.S.H.; Srinivasan, N.; Kasthurikrishnan, N.; Cooks, R.G.; Pincock, J.A.; Grossert, J.S.; J. Org. Chem. 1996, 61, 6627.

25. Johnson, R.C.; Koch, K.; Cooks, R.G.; Ind. Eng. Chem. Res. 1999, $38,343$.

26. Lago, R.M.; Nagem, N.F.; Dalmazio, I.; Augusti, R.; Rapid Commun. Mass Spectrom. 2003, 17, 1507.
27. Vieira, A.A.H.; Rev. Microbiol. 1983, 14, 202.

28. Franson, M.A.M.; Greenberg, A.E.; Trussell, R.R.; Clesceri, L.S.; Standard Methods for the Examination of Water and Wastewater, American Public Health Association: Washington, 1985.

29. Mendes, M.A.; Pimpim, R.S.; Kotiaho, T.; Barone, J.S.; Eberlin, M.N.; Quim. Nova 1996, 19, 480.

30. Linstrom, P.J.; Mallard, W.G.; J. Chem. Eng. Data 2001, 46, 1059.

31. Wachter, J.K.; Andelman, J.B.; Environ. Sci. Technol. 1984, 18, 811.

32. White, J.B.; Wastewater Engineering, Arnold: Baltimore, 1987.

33. Oliver, B.G.; Shindler, D.B.; Environ. Sci. Technol. 1980, 14, 1502.

34. Graham, N.J.D.; Water Sci. Technol. 1999, 40, 141.

35. Cheng, W.P.; Chi, F.H.; Chemosphere 2003, 53, 773.

Received: August 7, 2007

Web Release Date: May 5, 2008

FAPESP helped in meeting the publication costs of this article. 